\title{
An Investigation of Moroccan Vinegars: Their Physicochemical Properties and Antioxidant and Antibacterial Activities
}

\author{
Driss Ousaaid $\mathbb{D}^{1}{ }^{1}$ Hamada Imtara $\mathbb{D}^{1,2}$ Hassan Laaroussi ${ }^{1},{ }^{1}$ Badiaa Lyoussi $\left(\mathbb{D},{ }^{1}\right.$ \\ and Ilham Elarabi $\mathbb{D}^{1}$ \\ ${ }^{1}$ Laboratory of Natural Substances,Pharmacology, Environment,Modeling, Health and Quality of Life (SNAMOPEQ), \\ Faculty of Sciences Dhar El Mahraz, University Sidi Mohamed Ben Abdellah, Fez, Morocco \\ ${ }^{2}$ Faculty of Arts and Sciences, Arab American University Palestine, P.O. Box 240, Jenin, State of Palestine
}

Correspondence should be addressed to Driss Ousaaid; driss.ousaaid@usmba.ac.ma

Received 9 December 2020; Revised 20 January 2021; Accepted 31 January 2021; Published 10 February 2021

Academic Editor: Antimo Di Maro

Copyright $(92021$ Driss Ousaaid et al. This is an open access article distributed under the Creative Commons Attribution License, which permits unrestricted use, distribution, and reproduction in any medium, provided the original work is properly cited.

Vinegar is a natural product rich in bioactive compounds such as phenols, flavonoids, and organic acids. Several factors affect the quality of vinegars such as apple origin, environmental conditions, production methods, processing, and storage conditions. We investigated the quality of apple vinegars as well as their physicochemical properties and the antioxidant and antibacterial activities of vinegars collected from different areas in Morocco. For physicochemical properties, the outcomes showed the following values: $\mathrm{pH}(3.18-3.83)$, electrical conductivity (2.11-2.90), acidity (0.24-5.6), Brix (3.25-6), and density (1.0123-1.0233). The polyphenols content of samples was $68.91 \mathrm{mg} \mathrm{AG/100} \mathrm{mL} \mathrm{in} \mathrm{sample} \mathrm{S6} \mathrm{as} \mathrm{the} \mathrm{minimum} \mathrm{value} \mathrm{and}$ $147.54 \mathrm{mg} \mathrm{AG} / 100 \mathrm{~mL}$ in sample S2 as the maximum value. The best ability to scavenge the DPPH radical was observed in sample S3 $\left(\mathrm{IC}_{50}=0.45 \pm 0.013 \mu \mathrm{L} / \mathrm{mL}\right)$. Sample S2 showed moderate antibacterial effect against microorganisms tested with MICs ranging from $0.78 \mu \mathrm{L} / \mathrm{mL}$ to $1.125 \mu \mathrm{L} / \mathrm{mL}$ and with a diameter of inhibition ranging from $15.65 \mathrm{~mm}$ to $27.65 \mathrm{~mm}$. In addition, a strong correlation was observed between the antibacterial activity of vinegars and physicochemical parameters $(\mathrm{pH}$ and total acidity). These outcomes have shown that our vinegar samples are an excellent source of bioactive compounds with potent antioxidant and antibacterial potentials.

\section{Introduction}

Apple vinegar is an important source of therapeutic molecules. It is known for its antibacterial and antioxidant activities as it contains significant amounts of bioactivederivate compounds which play a major role in the treatment of bacterial infections [1-3].

Vinegar has a long history in Moroccan folk medicine; it has been used as a food condiment, as a preservative agent to maintain food color and quality, it is also used as an ingredient to remove odors, and, sometimes, as a healthy drink $[4,5]$. In addition, vinegar has various biological properties such as antidiabetic and antioxidant antimicrobial effects [6-8]. It possesses an antibacterial property due to its content of organic acids, mainly acetic acid [9]. Many organic acids are found naturally in apple vinegar in moderate concentrations which have no side effects on the health of consumers [9-11], such as acetic, lactic, ascorbic, citric, malic, propionic, succinic, and tartaric acids. Moreover, several studies have shown that organic acids destroy the outer membrane of bacterial cells, inhibit macromolecular synthesis, consume energy, and increase intracellular osmotic pressure of bacteria [12].

To our knowledge, no previous study aimed at a detailed characterization of Moroccan vinegars. Therefore, the main objective of this work was to investigate the physicochemical proprieties, the phytochemical content of apple vinegars purchased from different regions in Morocco, and their antioxidant and antibacterial activities for better evaluation of the quality of our vinegars. 


\section{Materials and Methods}

2.1. Vinegar Samples. The vinegar samples were purchased from different herbalist's shops and cooperatives installed in four different bioclimatic zones: Midelt, Azrou, Emmouzzer, and Sefrou (Table 1). The apple vinegars (based on the predominant varieties in this different area like Gloden delicious, Starking delicious, and Starkrimson) were named S1 and S2 from Midelt area, S3 from Azrou area, S4 and S5 from Imouzzer Kandar area, S6 and S7 from Sefrou area. The samples were kept at room temperature before carrying out the analyses.

\subsection{Determination of $p H$, Electric Conductivity, Total Acidity} (TA), Brix, and Density. $\mathrm{pH}$ and electric conductivity were determined using $\mathrm{pH}$ meter (OHAUS ST2100 F) and conductivimeter (CD20 conductivity meter), respectively, according to the method described by Rejsek [13]. The total acidity of vinegars was determined titrimetrically according to the French standard [14]. The Brix and density were measured using a refractometer. The various analyses were carried out in triplicate.

\subsection{Determination of Total Polyphenol Content (TPC) and} Total Flavonoid Content (TFC). The determination of the total polyphenols was carried out with the Folin-Ciocalteu colorimetric reagent according to the method described by Singleton et al. $[15,16]$. The concentration of total phenolic compounds was determined as $\mathrm{mg}$ of Gallic acid equivalent per $100 \mathrm{~mL}$ of vinegar, using a calibration curve. The total flavonoid content was determined according to the method described by Kong et al. $[15,17]$; the result was expressed as mg of quercetin equivalent per $100 \mathrm{~mL}$ of vinegar. The tests were carried out in triplicate.

\subsection{Determination of Total Antioxidant Capacity (TAC) and} Free Radical Scavenging Activity by DPPH Method. The total antioxidant capacity of vinegars was evaluated by the phosphomolybdenum method as previously described by Zengin et al. [18]. The total antioxidant capacity of the vinegars was evaluated as $\mathrm{mg}$ of ascorbic acid equivalent per $100 \mathrm{~mL}$ of vinegar. The scavenging activity of the samples for the radical 2,2-diphenyl-1-picrylhydrazyl (DPPH) was measured as described by Miguel et al. [19, 20]. The absorbance was recorded at $517 \mathrm{~nm}$. The tests were carried out in triplicate. The scavenging activity was estimated based on the percentage of DPPH radical scavenged using the following equation $[15,19]$ :

$\%$ inhibition $=\left[\frac{(\text { control absorbance }- \text { sample absorbance })}{(\text { control absorbance })}\right] * 100$.

The concentration providing 50\% radical inhibition (IC50) was calculated from the graph of inhibition percentage plotted against vinegars percentage [21].
TABLE 1: Geographical locations of apple vinegar samples studied.

\begin{tabular}{lccc}
\hline $\begin{array}{l}\text { Vinegar } \\
\text { symbol }\end{array}$ & Source & Latitude (N) & Longitude (W) \\
\hline S1 & Midelt & $32^{\circ} 40^{\prime} 48^{\prime \prime}$ & $4^{\circ} 44^{\prime} 48^{\prime \prime}$ \\
S2 & Azrou & $33^{\circ} 25^{\prime} 48^{\prime \prime}$ & $5^{\circ} 12^{\prime} 36^{\prime \prime}$ \\
\hline S3 & $\begin{array}{c}\text { Imouzzer } \\
\text { Kandar }\end{array}$ & $33^{\circ} 43^{\prime} 48^{\prime \prime}$ & $5^{\circ} 0^{\prime} 36^{\prime \prime}$ \\
\hline S4 & Sefrou & $33^{\circ} 49^{\prime} 48^{\prime \prime}$ & $4^{\circ} 49^{\prime} 48^{\prime \prime}$ \\
S5 & & &
\end{tabular}

2.5. Bacterial Strains and Inoculum Standardization. The E. coli BLSE (ATB: 87) BGN, E. coli (ATB: 57) B6N, E. coli (ATB: 97) BGM, and Pseudomonas aeruginosa strains are Gram-negative bacilli bacteria and were isolated from University Hospital Hassan II, while the Staphylococcus aureus strain (Gram-positive Cocci) was isolated from the Microbiology Laboratory of the FMP, Fez. The bacterial growth was carried out at $37^{\circ} \mathrm{C}$ in Mueller-Hinton Broth (MHB) liquid medium and on Mueller-Hinton Agar (MHA). The suspension bacterial (inoculums) was obtained by taking colonies from 24-hour cultures. The colonies were suspended in physiological saline $(0.9 \% \mathrm{NaCl})$ and shacked for 15 seconds and the density was adjusted to a turbidity of $0.5 \mathrm{McF}$ arland, which corresponds to an optical density of $0.08-0.13$ measured at a wavelength of $625 \mathrm{~nm}$. The final concentration of the inoculum was approximately $10^{8} \mathrm{CFU} / \mathrm{mL}$ [22].

2.6. Agar Well Diffusion (AWD) Assay. Preliminary screening of the antimicrobial activity of vinegars was performed by the Kirby-Bauer method [23]. With modifications, Mueller-Hinton agar plates are inoculated by swabbing from the standardized suspensions $\left(10^{8} \mathrm{CFU} / \mathrm{mL}\right)$. Then, Whatman paper disks $(6 \mathrm{~mm})$ are deposited on the surface of the preinoculated agar. Then, the disks are impregnated with $100 \mu \mathrm{L}$ of each vinegar. All plates were incubated at $37^{\circ} \mathrm{C}$ for 24 hours. After incubation, the diameters of the inhibition zones were measured.

\subsection{Determination of the Minimum Inhibitory Concentration} (MIC) and Minimal Bactericidal Concentration (MBC). The MICs were studied according to the microdilution assays in 96-well microtiter plates [24]. With modifications, ten concentrations of apple vinegars are prepared in sterile hemolysis tubes and carried out by successive dilutions $1 / 2$ in distilled water ranging from $1 / 2$ to $1 / 512$ of vinegar solution. Bacterial suspensions were prepared in the same way described previously were diluted in $\mathrm{MH}$ broth and plated in 96-well plates at a density of $5.0 \times 10^{5} \mathrm{CFU}$ well ${ }^{-1}$. Finally, the plates were incubated at $37^{\circ} \mathrm{C}$ for $18 \mathrm{~h} .40 \mu \mathrm{L}$ of $0.5 \%$ triphenyltetrazolium chloride (TTC) was added to each well. MIC corresponds to the lowest dose that does not produce red color [22]. To determine $\mathrm{MBC}$, a portion from each well in which the concentrations are $>$ or $=(\mathrm{MIC})$ was subcultured on Muller-Hinton agar $(\mathrm{MHA})$ and incubated at $37^{\circ} \mathrm{C}$ for $24 \mathrm{~h}$. The $\mathrm{MBC}$ is defined as the lowest concentration of the extracts at which inoculated bacteria were $99.9 \%$ killed [22]. 
2.8. Statistical Analysis. The statistical analyses were performed by Pearson correlation coefficient $(r)$ at a significance level of $99 \%(p<0.01)$. The data preprocessing and the PCA were accomplished using MultBiplot64 running in MATLAB R2017a. Comparisons of apple vinegar samples were performed by Tukey test using SPSS 23 software.

\section{Results and Discussion}

3.1. Physicochemical Properties. Table 2 illustrates the physicochemical characterizations of the analyzed samples. The recorded $\mathrm{pH}$ of vinegars varied between 3.18 and 3.83. Our vinegar samples have the ability to allow the passage of electrical current; the electrical conductivity values were between 2.90 and $2.11 \mathrm{mS} / \mathrm{cm}$. It depends on the mineral content [25]. The total acidity values of analyzed vinegar samples vary between 0.24 and $5.6 \mathrm{mg}$ of acetic acid per $100 \mathrm{~mL}$ of vinegar.

In fact, the Decree no. 2-10-385 regulating the manufacture and trade of vinegars [26] set the minimum value of this parameter at $5 \mathrm{~g}$ of acetic acid per $100 \mathrm{~mL}$ of vinegar. These results are in agreement with those reported by Ousaaid et al. [27]. The ${ }^{\circ}$ Brix of our samples was also found to range between 3.25 and 6 , and the density values were between 1.0123 and 1.0233 . These results are in agreement with those reported by previous studies $[28,29]$.

Physicochemical parameters are generally within the range indicated by other studies [30-34]. S1, S2, and S6 have acidity values included in the norms required by the Moroccan legislation. Our results are in line with previous reports $[30,33]$. The acidity confers vinegar's antimicrobial properties $[27,35,36]$.

3.2. Antioxidant Capacity. The determination of the antioxidant profile of the seven vinegars was studied using four assays; the outcomes are shown in Table 3 . Phenolic content values varied in the range of $68.91 \pm 4.5 \mathrm{mg} \mathrm{GAE} / 100 \mathrm{~mL}$ (S6) to $147.54 \pm 12.1 \mathrm{mg} \mathrm{GAE} / 100 \mathrm{~mL}$ (S2). The highest value of flavonoids was established in S2 $(14.76 \pm 0.43 \mathrm{mg}$ QE/ $100 \mathrm{~mL}$ ), while the lowest value was detected in $\mathrm{S} 1$ $(4.72 \pm 0.20 \mathrm{mg} \mathrm{QE} / 100 \mathrm{~mL})$. The results obtained are in accordance with those reported by Ozturk et al. [33]. The statistical comparison showed that the total phenolic content (TPC) of different samples was significantly different $(p<0.05)$.

The highest total antioxidant capacity (TAC) was founded in S2 with a value of $13.27 \pm 0.47 \mathrm{mg} \mathrm{AAE} / 100 \mathrm{~mL}$ and the minimum value was established in $\mathrm{S} 4$ with a value of $2.29 \pm 0.58 \mathrm{mg} \mathrm{AAE} / 100 \mathrm{~mL}$. The S3, S4, and S7 have the best ability to scavenge the free radicals in the DPPH assay with the recorded values $\mathrm{IC}_{50}=0.45 \pm 0.013, \mathrm{IC}_{50}=0.47 \pm 0.003$ and $\mathrm{IC}_{50}=0.46 \pm 0.006 \mu \mathrm{L} / \mathrm{mL}$, respectively. Additionally, the negative correlation could be seen clearly between the bioactive compounds (phenols and flavonoids) and the DPPH IC50\% $(r=-0.033048 ; p<0.05$ and $r=-0.58876$, $p<0.05$, resp.) (Table 4).
3.3. Antibacterial Activity. Table 5 describes the susceptibility of Gram-negative and Gram-positive bacterial strains to the seven apple vinegar samples by measuring the inhibition zones (in $\mathrm{mm}$ ). The antibacterial capacity of all examined samples, except sample S7, revealed a positive effect against five bacterial strains with a range of inhibition zones between $11.1 \pm 0.14$ and $27.65 \pm 0.91 \mathrm{~mm}$. The S2 was the most effective sample against all bacterial strains because it inhibited the growth of all isolates with an inhibition zone ranged between 15,65 $\pm 0,49 \mathrm{~mm}$ for Pseudomonas aeruginosa and $27.65 \pm 0.91 \mathrm{~mm}$ for Staphylococcus aureus $(p<0.05)$. In contrast, S7 had no effect on the bacterial strains; the weakest effect obtained was with S5 with $11.1 \pm 0.14 \mathrm{~mm}$ and $11.6 \pm 0.84 \mathrm{~mm}$ against Escherichia coli (ATB:87) and Escherichia coli (ATB:57), respectively, and S3 with $11.05 \pm 0.07 \mathrm{~mm}, 14.85 \pm 0.21 \mathrm{~mm}$, and $12.5 \pm 0.70 \mathrm{~mm}$ against Pseudomonas aeruginosa, Staphylococcus aureus, and Escherichia coli (ATB:97), respectively.

Table 5 summarizes the outcomes of minimum inhibitory concentrations (MICs) and minimum bactericidal concentrations (MBCs) of each apple vinegar against all studied bacterial strains. The MIC values of vinegars ranged from $0.781 \mu \mathrm{L} / \mathrm{mL}$ to $12.5 \mu \mathrm{L} / \mathrm{mL}$ on five strains and MBCs values ranged from 3.125 to $50 \mu \mathrm{L} / \mathrm{mL}$. Amongst the tested bacterial strains, Staphylococcus aureus was the most sensitive for all examined samples, it was inhibited by 1.125 to $50 \mu \mathrm{L}$ of vinegar and killed by 6.25 to $50 \mu \mathrm{L}$ of vinegar (Table 3). Escherichia coli (ATB:87) was the most resistant for S1 and S5 (MICs: $3.125 \mu \mathrm{L}$; MBCs: $6.25 \mu \mathrm{L}$ ); Pseudomonas aeruginosa was the most resistant for S2 and S3 (MICs: 0.781 and $12.5 \mu \mathrm{L}$; MIBCs: 3.125 and $25 \mu \mathrm{L}$, resp.). Escherichia coli (ATB:57) was the most resistant for S4 and S6 (MICs: 3.125 and $3.125 \mu \mathrm{L}$; MBCs: 12.5 and $3.125 \mu \mathrm{L}$ of vinegar, resp.).

The antibacterial activity of Moroccan vinegars against five microorganisms was assessed qualitatively and quantitatively by the presence or absence of inhibition zones, the corresponding zone diameters, and MIC and MBC values. Apple vinegar, produced by ancestral methods, is commonly used in folk medicine and is known to have several physiological functions [7, 12]. Generally, the Gram-positive strain of bacteria tested in this study (Staphylococcus aureus) is sensitive to our vinegar samples, these results are in agreement with previous reports $[8,33,37-39]$. We also recorded a significant susceptibility of the examined Gramnegative bacteria. In the literature, many active functions of vinegar have been reported by several studies including antibacterial activity $[35,36,38,40]$. The activity of apple vinegar is thought to be due to the presence of organic acids. These acids have an antimicrobial effect, mainly acetic acid which passes into bacterial membrane thus decreasing the intracellular $\mathrm{pH}$ and causing microorganisms' death [41, 42]. Several researchers have demonstrated the antibacterial effect of organic acids on different bacterial strains $[8,38,41,42]$. Previous studies have reported that apple vinegar was effective against Staphylococcus aureus, Streptococcus pyogenes, Proteus mirabilis [38] and Pseudomonas aeruginosa, Pseudomonas fluorescens, Pseudomonas vulgaris, Salmonella typhi, and Klebsiella pneumonia [8, 33]. Ozturk et al. and Rutala et al. [33, 40] demonstrated that vinegars 
TABLE 2: Vinegars physicochemical characterization.

\begin{tabular}{|c|c|c|c|c|c|c|}
\hline Region/sample & & $p \mathrm{H}$ & Electric conductivity $(\mathrm{mS} / \mathrm{cm})$ & Titratable acidity (\%) & ${ }^{\circ}$ Brix & Density \\
\hline \multirow{2}{*}{ Midelt } & S1 & $3.18 \pm 0.015^{\mathrm{d}}$ & $2.79 \pm 0.005^{\mathrm{ab}}$ & $5.4 \pm 0.1^{\mathrm{a}}$ & $5.2^{\mathrm{b}}$ & $1.020 \pm 0.0003^{\mathrm{a}}$ \\
\hline & S2 & $3.19 \pm 0.005^{\mathrm{d}}$ & $2.72 \pm 0.015^{\mathrm{b}}$ & $5.6 \pm 0.1^{\mathrm{a}}$ & $3.25^{\mathrm{d}}$ & $1.0123 \pm 0.0001^{\mathrm{a}}$ \\
\hline Azrou & S3 & $3.47 \pm 0.035^{\mathrm{b}}$ & $2.74 \pm 0.032^{b}$ & $0.99 \pm 0.04^{\mathrm{d}}$ & $5.6^{\mathrm{ab}}$ & $1.0205 \pm 0.0016^{\mathrm{a}}$ \\
\hline \multirow{2}{*}{ Imouzzer Kandar } & S4 & $3.54 \pm 0.028^{b}$ & $2.80 \pm 0.009^{b}$ & $3.04 \pm 0.07^{\mathrm{b}}$ & $4^{\mathrm{c}}$ & $1.0156 \pm 0.0003^{\mathrm{a}}$ \\
\hline & S5 & $3.42 \pm 0.027^{b c}$ & $2.90 \pm 0.015^{\mathrm{a}}$ & $2.19 \pm 0.04^{\mathrm{c}}$ & $5.22^{\mathrm{b}}$ & $1.0233 \pm 0.0011^{\mathrm{a}}$ \\
\hline \multirow{2}{*}{ Sefrou } & S6 & $3.32 \pm 0.007^{\mathrm{c}}$ & $2.11 \pm 0.011^{c}$ & $5.42 \pm 0.02^{\mathrm{a}}$ & $6^{\mathrm{a}}$ & $1.0217 \pm 0.0022^{\mathrm{a}}$ \\
\hline & S7 & $3.83 \pm 0.003^{\mathrm{a}}$ & $2.11 \pm 0.005^{\mathrm{c}}$ & $0.24 \pm 0.007^{\mathrm{e}}$ & $5.5^{\mathrm{ab}}$ & $1.0203 \pm 0.0013^{\mathrm{a}}$ \\
\hline
\end{tabular}

Values in the same column followed by the same letter are not significantly different by Tukey's multiple range test $(p<0.05)$.

TABle 3: Phytochemical content and antioxidant activities of vinegars.

\begin{tabular}{lccccc}
\hline Region & Sample & $\begin{array}{c}\text { Polyphenols mg GAE } \\
(100 \mathrm{~mL})\end{array}$ & Flavonoids mg QE $(100 \mathrm{~mL})$ & TAC mg AAE $(100 \mathrm{~mL})$ & IC50\% DPPH $\mu \mathrm{L}(\mathrm{mL})$ \\
\hline \multirow{2}{*}{ Midelt } & $\mathrm{S} 1$ & $118.25 \pm 6.5^{\mathrm{ab}}$ & $4.72 \pm 0.20^{\mathrm{c}}$ & $10.89 \pm 0.54^{\mathrm{b}}$ & $0.92 \pm 0.014^{\mathrm{b}}$ \\
& $\mathrm{S} 2$ & $147.54 \pm 12.1^{\mathrm{a}}$ & $14.76 \pm 0.43^{\mathrm{ab}}$ & $13.27 \pm 0.47^{\mathrm{a}}$ & $0.71 \pm 0.039^{\mathrm{c}}$ \\
\hline Azrou & $\mathrm{S} 3$ & $97.08 \pm 7.5^{\mathrm{bc}}$ & $13.93 \pm 3.16^{\mathrm{ab}}$ & $12.33 \pm 0.09^{\mathrm{ab}}$ & $0.45 \pm 0.013^{\mathrm{d}}$ \\
\hline Imouzzer & $\mathrm{S} 4$ & $81.33 \pm 6.91^{\mathrm{bc}}$ & $7.34 \pm 0.32^{\mathrm{bc}}$ & $2.17 \pm 0.18^{\mathrm{e}}$ & $0.47 \pm 0.003^{\mathrm{d}}$ \\
Kandar & $\mathrm{S} 5$ & $95 \pm 4.58^{\mathrm{bc}}$ & $5.42 \pm 0.80^{\mathrm{c}}$ & $13.53 \pm 0.07^{\mathrm{a}}$ & $0.66 \pm 0.005^{\mathrm{c}}$ \\
\hline \multirow{2}{*}{ Sefrou } & $\mathrm{S} 6$ & $68.91 \pm 4.5^{\mathrm{c}}$ & $5.14 \pm 1.64^{\mathrm{c}}$ & $5.44 \pm 0.08^{\mathrm{d}}$ & $1.19 \pm 0.014^{\mathrm{a}}$ \\
& $\mathrm{S} 7$ & $88.91 \pm 2.33^{\mathrm{bc}}$ & $15.32 \pm 0.20^{\mathrm{a}}$ & $8.62 \pm 0.06^{\mathrm{c}}$ & $0.46 \pm 0.006^{\mathrm{d}}$ \\
\hline
\end{tabular}

Values in the same column followed by the same letter are not significantly different by Tukey's multiple range test $(p<0.05)$.

TABLE 4: Pearson correlation coefficients between the assessed physicochemical parameters and diameter of inhibition (DI) and MICs of vinegar samples.

\begin{tabular}{|c|c|c|c|c|c|c|c|c|c|c|c|}
\hline & $\begin{array}{l}\text { DPPH } \\
\text { (IC50) }\end{array}$ & $\begin{array}{c}\text { DI E. coli } \\
87\end{array}$ & $\begin{array}{c}\text { DI } \\
\text { P. aeruginosa }\end{array}$ & $\begin{array}{c}\text { DI } \\
\text { S. aureus }\end{array}$ & $\begin{array}{c}\text { DI E. coli } \\
57\end{array}$ & $\begin{array}{c}\text { DI E. coli } \\
466\end{array}$ & $\begin{array}{c}\text { MIC } \\
\text { E. coli } \\
87\end{array}$ & $\begin{array}{c}\text { MIC } \\
\text { P. aeruginosa }\end{array}$ & $\begin{array}{c}\text { MIC } \\
\text { S. aureus }\end{array}$ & $\begin{array}{l}\text { MIC } \\
\text { E. coli } \\
57\end{array}$ & $\begin{array}{c}\text { MIC } \\
\text { E. coli } \\
466\end{array}$ \\
\hline $\mathrm{pH}$ & -0.662 & $-0.889 * *$ & $-0.856 *$ & $-0.885 * *$ & $-0.912 * *$ & $-0.930 * *$ & $0.842 *$ & $0.765 *$ & $0.908 * *$ & $0.826 *$ & $0.820 *$ \\
\hline TA & $0.809 *$ & $0.840 *$ & $0.808 *$ & $0.885 * *$ & $0.796 *$ & $0.787 *$ & $-0.808 *$ & $-0.887 * *$ & $-0.877 * *$ & $-0.776 *$ & $-0.764 *$ \\
\hline Phenols & -0.033 & 0.390 & 0.139 & 0.283 & 0.417 & 0.373 & -0.222 & -0.268 & -0.285 & -0.212 & -0.208 \\
\hline Flavonoids & -0.589 & -0.292 & -0.633 & -0.482 & -0.312 & -0.489 & 0.637 & 0.642 & 0.584 & 0.654 & 0.659 \\
\hline TAC & -0.053 & 0.098 & -0.061 & -0.043 & 0.170 & 0.208 & 0.022 & 0.097 & -0.025 & -0.012 & -0.023 \\
\hline
\end{tabular}

$* *$ The correlation is significant at the 0.01 level. $*$ The correlation is significant at the 0.05 level. DI : diameters of inhibition zones; TA: titratable acidity; TAC: total antioxidant capacity.

TABle 5: Diameters of inhibition zones (DI) and MICs and MBCs values of vinegar samples generated against different bacterial strains.

\begin{tabular}{|c|c|c|c|c|c|c|c|}
\hline & & & $\begin{array}{c}\text { Escherichia coli BLSE } \\
\text { (ATB:87) BGN }\end{array}$ & $\begin{array}{c}\text { Pseudomonas } \\
\text { aeruginosa }\end{array}$ & $\begin{array}{c}\text { Staphylococcus } \\
\text { aureus }\end{array}$ & $\begin{array}{l}\text { Escherichia coli } \\
\text { (ATB:57) B6N }\end{array}$ & $\begin{array}{l}\text { Escherichia coli } \\
\text { (ATB:97) BGM }\end{array}$ \\
\hline \multirow{6}{*}{ Midelt } & \multirow{4}{*}{$\mathrm{S} 1$} & DI (mm) & $13.55 \pm 0.63^{\mathrm{ab}}$ & $15.6 \pm 0.56^{\mathrm{b}}$ & $22.5 \pm 2.12^{\mathrm{abc}}$ & $13.75 \pm 0.35^{\mathrm{bc}}$ & $16.5 \pm 0.70^{\mathrm{ab}}$ \\
\hline & & $\begin{array}{c}\text { MIC } \\
(\mu \mathrm{L} / \mathrm{mL})\end{array}$ & 3.125 & 1.562 & 3.125 & 3.125 & 3.125 \\
\hline & & $\begin{array}{c}\mathrm{MBC} \\
(\mu \mathrm{L} / \mathrm{mL})\end{array}$ & 3.125 & 6.25 & 12.5 & 6.25 & 6.25 \\
\hline & & $\mathrm{DI}(\mathrm{mm})$ & $20.5 \pm 0.70^{\mathrm{a}}$ & $15.65 \pm 0.49^{\mathrm{b}}$ & $27.65 \pm 0.91^{\mathrm{a}}$ & $18.85 \pm 0.21^{\mathrm{a}}$ & $18.95 \pm 0.07^{\mathrm{a}}$ \\
\hline & \multirow[t]{2}{*}{$\mathrm{S} 2$} & $\begin{array}{c}\mathrm{MIC} \\
(\mu \mathrm{L} / \mathrm{mL})\end{array}$ & 1.125 & 0.781 & 1.125 & 1.125 & 1.125 \\
\hline & & $\begin{array}{c}\mathrm{MBC} \\
(\mu \mathrm{L} / \mathrm{mL})\end{array}$ & 3.125 & 3.125 & 6.25 & 6.25 & 3.125 \\
\hline \multirow{3}{*}{ Azrou } & \multirow{3}{*}{ S3 } & DI (mm) & $11.7 \pm 0.42^{\mathrm{b}}$ & $11.05 \pm 0.07^{\mathfrak{c}}$ & $14.85 \pm 0.21^{\mathrm{c}}$ & $12.45 \pm 0.63^{\mathrm{c}}$ & $12.5 \pm 0.70^{c}$ \\
\hline & & $\begin{array}{c}\text { MIC } \\
(\mu \mathrm{L} / \mathrm{mL})\end{array}$ & 12.5 & 12.5 & 12.5 & 12.5 & 12.5 \\
\hline & & $\begin{array}{c}\mathrm{MBC} \\
(\mu \mathrm{L} / \mathrm{mL})\end{array}$ & 12.5 & 25 & 25 & 12.5 & 25 \\
\hline
\end{tabular}


TABLE 5: Continued.

\begin{tabular}{|c|c|c|c|c|c|c|c|}
\hline & & & $\begin{array}{c}\text { Escherichia coli BLSE } \\
\text { (ATB:87) BGN }\end{array}$ & $\begin{array}{c}\text { Pseudomonas } \\
\text { aeruginosa }\end{array}$ & $\begin{array}{c}\text { Staphylococcus } \\
\text { aureus }\end{array}$ & $\begin{array}{l}\text { Escherichia coli } \\
\text { (ATB:57) B6N }\end{array}$ & $\begin{array}{l}\text { Escherichia coli } \\
\text { (ATB:97) BGM }\end{array}$ \\
\hline \multirow{6}{*}{$\begin{array}{l}\text { Imouzzer } \\
\text { Kandar }\end{array}$} & \multirow{3}{*}{ S4 } & $\mathrm{DI}(\mathrm{mm})$ & $12.5 \pm 0.56^{\mathrm{a}}$ & $14.85 \pm 0.21^{\mathrm{b}}$ & $21.52 \pm 0.67^{\mathrm{bc}}$ & $12.01 \pm 0.007^{\mathrm{c}}$ & $13.25 \pm 1.06^{\mathrm{bc}}$ \\
\hline & & $\begin{array}{c}\text { MIC } \\
(\mu \mathrm{L} / \mathrm{mL})\end{array}$ & 3.125 & 3.125 & 6.25 & 3.125 & 3.125 \\
\hline & & $\begin{array}{c}\mathrm{MBC} \\
(\mu \mathrm{L} / \mathrm{mL})\end{array}$ & 6.25 & 6.25 & 12.5 & 12.5 & 6.25 \\
\hline & \multirow{3}{*}{ S5 } & $\mathrm{DI}(\mathrm{mm})$ & $11.1 \pm 0.14^{\mathrm{ab}}$ & $13.75 \pm 0.35^{\mathrm{b}}$ & $17.6 \pm 0.56^{\mathrm{cd}}$ & $11.6 \pm 0.84^{\mathrm{c}}$ & $15.69 \pm 0.55^{\mathrm{abc}}$ \\
\hline & & $\begin{array}{c}\mathrm{MIC} \\
(\mu \mathrm{L} / \mathrm{mL})\end{array}$ & 3.125 & 3.125 & 6.25 & 1.25 & 0.625 \\
\hline & & $\begin{array}{c}\mathrm{MBC} \\
(\mu \mathrm{L} / \mathrm{mL})\end{array}$ & 6.25 & 6.25 & 12.5 & 12.5 & 6.25 \\
\hline \multirow{6}{*}{ Sefrou } & \multirow{3}{*}{ S6 } & $\mathrm{DI}(\mathrm{mm})$ & $17.5 \pm 0.70^{\mathrm{ab}}$ & $17.95 \pm 0.21^{\mathrm{a}}$ & $26.75 \pm 0.35^{\mathrm{ab}}$ & $15.5 \pm 0.70^{\mathrm{b}}$ & $16.54 \pm 0.64^{\mathrm{ab}}$ \\
\hline & & $\begin{array}{c}\mathrm{MIC} \\
(\mu \mathrm{L} / \mathrm{mL})\end{array}$ & 1.562 & 1.562 & 1.562 & 1.562 & 1.562 \\
\hline & & $\begin{array}{c}\mathrm{MBC} \\
(\mu \mathrm{L} / \mathrm{mL})\end{array}$ & 3.125 & 3.125 & 6.25 & 3.125 & 3.125 \\
\hline & \multirow{3}{*}{ S7 } & $\mathrm{DI}(\mathrm{mm})$ & - & - & - & - & - \\
\hline & & $\begin{array}{c}\mathrm{MIC} \\
(\mu \mathrm{L} / \mathrm{mL})\end{array}$ & 25 & 12.5 & 25 & 25 & 25 \\
\hline & & $\begin{array}{c}\mathrm{MBC} \\
(\mu \mathrm{L} / \mathrm{mL})\end{array}$ & 50 & 25 & 50 & 50 & 25 \\
\hline
\end{tabular}

Values in the same column followed by the same letter are not significantly different by Tukey's multiple range test $(p<0.05)$.

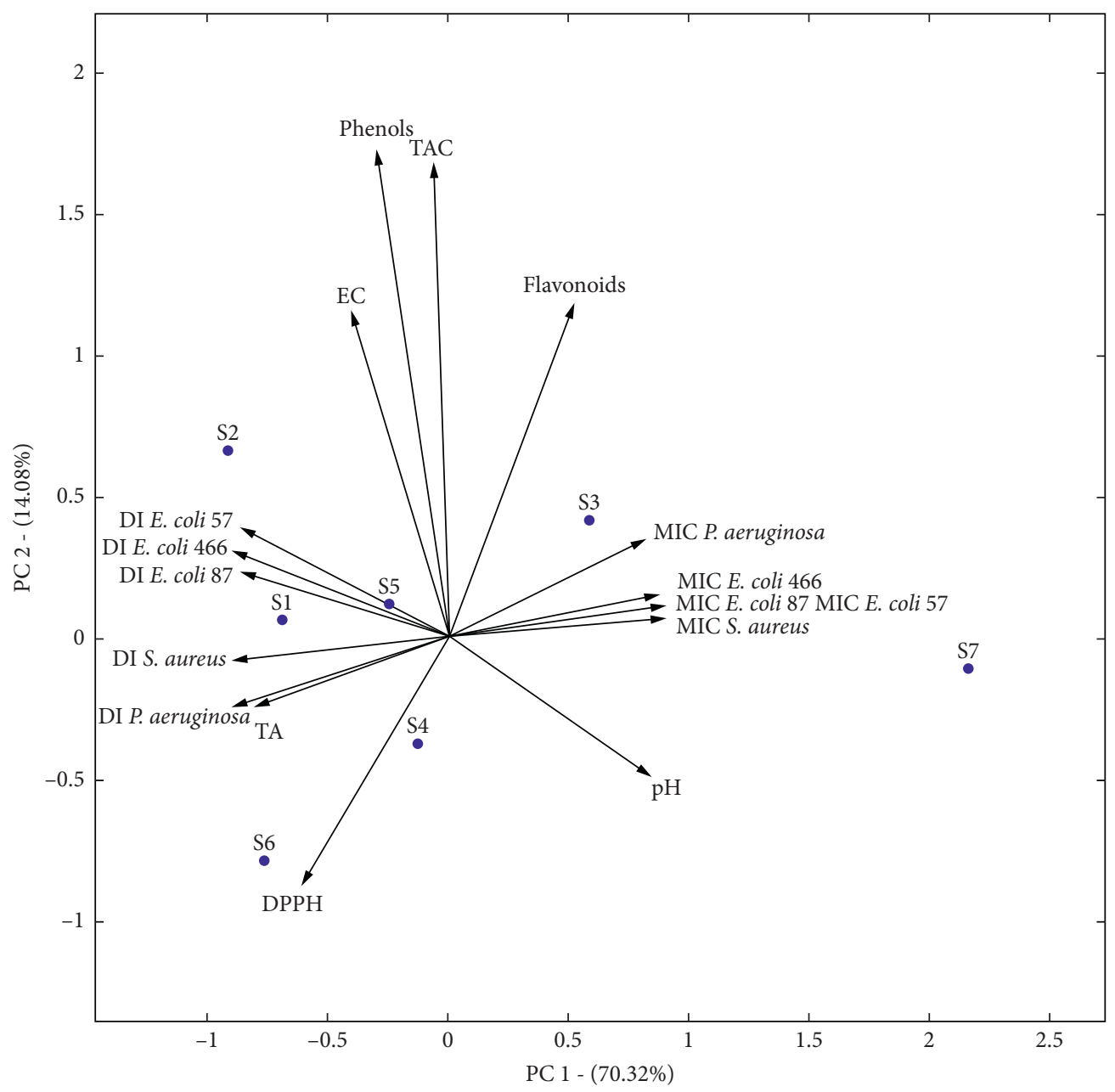

Figure 1: Principal component analysis (PCA) of the analyzed vinegar samples using the assessed parameters as an input: phenols, flavonoids, $\mathrm{IC}_{50}, \mathrm{DPPH}$, and $\mathrm{pH}$. TAC: total antioxidant capacity; TA: total acidity; EC: electrical conductivity; DI: diameters of the inhibition zones; MIC: minimum inhibitory concentration. 
have substantial activity against $P$. aeruginosa and S. choleraesuis and are not effective against E. coli or $S$. aureus. Furthermore, the vinegar phenolic content and antibacterial activity have a direct relationship [43]; the antibacterial effect could be influenced by the phenolic composition $[43,44]$. In this work, all studied apple vinegar samples showed high phenolic compounds content, which could be responsible for the documented antibacterial action.

3.4. Multivariate Analysis. To understand the distribution of the vinegars based on the assessed parameters it is necessary to use statistical tools such as PCA which is an excellent tool to explore the link between variables and similarities between samples [45].

The evaluated parameters were concentrated in a single group formed by all parameters studied (Figure 1). In the present work, the first two principal components accounted for $70.32 \%$ and $14.08 \%$ successively of the information contained in the original data matrix (Figure 1). The first principal component (PC), the component that keeps major information, correlated positively with $\mathrm{pH}$ and flavonoids, as well as the rest of the results of antibacterial activity by minimum inhibitory concentration method. Therefore, a negative correlation can be observed between the same PC and phenols, TA, EC, and antioxidant and antibacterial activities. Considering the similarities of the samples, the first PC allowed the distinction of two groups, each of which had similar characteristics in terms of antioxidant and antibacterial activities. The first group, composed of S1 and S2 samples, had high phenol content and thus high antioxidant and antibacterial effects. This group is located in the negative part of the graph. The S7 sample had the opposite characteristics and present in the right part of the graph.

\section{Conclusion}

This pioneering study in Morocco made it possible to determine the physicochemical parameters and antioxidant activities of apple vinegars from several regions of Morocco. The characterization of these parameters is very important in order to use them as quality standards for apple vinegar in Morocco and thus protect consumers from frauds. The antibacterial results in the present study also show the importance of vinegar in the treatment of infectious diseases. Further investigations are desirable to study the molecular mechanisms responsible for this activity to develop new treatment multidrug resistant bacterial infections.

\section{Data Availability}

The data used to support the findings of this study are included within the article.

\section{Conflicts of Interest}

The authors declare that they have no conflicts of interest.

\section{Acknowledgments}

The authors are grateful to their colleagues who helped in collecting data and the agricultural cooperatives in Midelt, Azrou, Imouzzer Kandar, and Sefrou.

\section{References}

[1] M. Ahmadniaye, O. Safari, and M. Paolucci, "Effect of different levels of milkweed (Calotropis persica) seed powder on the growth parameters, immunity and gut microbiota of oncorhynchus mykiss," Iranian Journal of Veterinary Science and Technology, vol. 11, no. 1, pp. 43-67, 2019.

[2] T. P. T. Cushnie and A. J. Lamb, "Recent advances in understanding the antibacterial properties of flavonoids," International Journal of Antimicrobial Agents, vol. 38, no. 2, pp. 99-107, 2011.

[3] O. Safari and M. Sarkheil, "Dietary administration of eryngii mushroom (Pleurotus eryngii) powder on haemato-immunological responses, bactericidal activity of skin mucus and growth performance of koi carp fingerlings (Cyprinus carpio koi)," Fish \& Shellfish Immunology, vol. 80, pp. 505-513, 2018.

[4] L. Solieri and P. Giudici, "Vinegars of the world," in Vinegars of the World [Internet], L. Solieri and P. Giudici, Eds., Springer, Milano, Italy, pp. 1-16, 2019.

[5] W. Tesfaye, M. L. Morales, M. C. Garćia-Parrilla, and A. M. Troncoso, "Wine vinegar: technology, authenticity and quality evaluation," Trends in Food Science \& Technology, vol. 13, no. 1, pp. 12-21, 2002.

[6] S. Bakir, G. Toydemir, D. Boyacioglu, J. Beekwilder, and E. Capanoglu, "Fruit antioxidants during vinegar processing: changes in content and in vitro bio-accessibility," International Journal of Molecular Sciences, vol. 17, no. 10, p. 1658, 2016.

[7] N. H. Budak, E. Aykin, A. C. Seydim, A. K. Greene, and Z. B. Guzel-Seydim, "Functional properties of vinegar," Journal of Food Science, vol. 79, no. 5, pp. R757-R764, 2014.

[8] N. K. Hindi, "In vitro antibacterial activity of aquatic garlic extract, apple vinegar and apple vinegar-garlic extract combination," Am J Phytomedicine Clin Ther, vol. 1, no. 1, pp. 42-51, 2013.

[9] J.-H. Ryu, Y. Deng, and L. R. Beuchat, "Behavior of acidadapted and unadapted Escherichia coli O157:H7 when exposed to reduced $\mathrm{pH}$ achieved with various organic acids," Journal of Food Protection, vol. 62, no. 5, pp. 451-455, 1999.

[10] Q. Liu, G.-Y. Tang, C.-N. Zhao et al., "Antioxidant activities, phenolic profiles, and organic acid contents of fruit vinegars," Antioxidants, vol. 8, no. 4, p. 78, 2019.

[11] D. Sanarico, S. Motta, L. Bertolini, and A. Antonelli, "HPLC determination of organic acids in traditional balsamic vinegar of reggio emilia," Journal of Liquid Chromatography \& Related Technologies, vol. 26, no. 13, pp. 2177-2187, 2003.

[12] H. Chen, T. Chen, P. Giudici, and F. Chen, "Vinegar functions on health: constituents, sources, and formation mechanisms," Comprehensive Reviews in Food Science and Food Safety, vol. 15, no. 6, pp. 1124-1138, 2016.

[13] F. Rejsek, "Analyses es eaux. Aspects réglementaire et techniques,” Ed. Scéren, pp. 69-74, Paris, France, 2002.

[14] N. F. V05-101, "Détermination de la teneur en acidité volatile in Fruits," légumes et produits dérivés, 1974.

[15] M. Bakour, N. S. Al-Waili, N. El Menyiy et al., "Antioxidant activity and protective effect of bee bread (honey and pollen) in aluminum-induced anemia, elevation of inflammatory 
makers and hepato-renal toxicity," Journal of Food Science and Technology, vol. 54, no. 13, pp. 4205-4212, 2017.

[16] V. L. Singleton, R. Orthofer, and R. M. Lamuela-Raventós, Analysis of Total Phenols and Other Oxidation Substrates and Antioxidants by Means of Folin-Ciocalteu Reagent, vol. Vol. 299, pp. 152-178, Academic Press, Cambridge, MA, USA, 1999.

[17] K. W. Kong, S. Mat-Junit, N. Aminudin, A. Ismail, and A. Abdul-Aziz, "Antioxidant activities and polyphenolics from the shoots of Barringtonia racemosa (L.) Spreng in a polar to apolar medium system," Food Chemistry, vol. 134, no. 1, pp. 324-332, 2012.

[18] G. Zengin, T. Arkan, A. Aktumsek, G. O. Guler, and Y. S. Cakmak, "A study on antioxidant capacities and fatty acid compositions of TwoDaphneSpecies from Turkey: new sources of antioxidants and essential fatty acids," Journal of Food Biochemistry, vol. 37, no. 6, pp. 646-653, 2013.

[19] M. d. G. Miguel, O. Doughmi, S. Aazza, D. Antunes, and B. Lyoussi, "Antioxidant, anti-inflammatory and acetylcholinesterase inhibitory activities of propolis from different regions of Morocco," Food Science and Biotechnology, vol. 23, no. 1, pp. 313-322, 2014.

[20] J. S. Hogg, D. H. Lohmann, and K. E. Russell, "The kinetics of reaction of 2,2-diphenyl-1-picrylhydrazyl with phenols," Canadian Journal of Chemistry, vol. 39, no. 8, pp. 1588-1594, 1961.

[21] H. Imtara, Y. Elamine, and B. Lyoussi, "Honey antibacterial effect boosting using Origanum vulgare L. essential oil," Evidence-Based Complementary and Alternative Medicine, vol. 2018, Article ID 7842583, 14 pages, 2018.

[22] D. Dimitrijević, S. M. Stanković, and Z. Stojanović-Radić, "Ran $\backslash d$ jelović V, Lakušić D. Antioxidant and antimicrobial activity of different extracts from leaves and roots of Jovibarba heuffelii (Schott.) A. Löve and D. Löve," Journal of Medicinal Plants Research.vol. 6, no. 33, pp. 4804-4810, 2012.

[23] G. L. Furtado and A. A. Medeiros, "Single-disk diffusion testing (Kirby-Bauer) of susceptibility of Proteus mirabilis to chloramphenicol: significance of the intermediate category," Journal of Clinical Microbiology, vol. 12, no. 4, pp. 550-553, 1980.

[24] R. N. Master, D. C. Draghi, M. E. Jones, C. Thornsberry, D. F. Sahm, and J. A. Karlowsky, "Tracking the implementation of NCCLS M100-S12 expanded-spectrum cephalosporin MIC breakpoints for nonmeningeal isolates of Streptococcus pneumoniae by clinical laboratories in the United States during 2002 and 2003," Annals of Clinical Microbiology and Antimicrobials, vol. 3, no. 1, p. 1, 2004.

[25] S. Bogdanov, T. Jurendic, R. Sieber, and P. Gallmann, "Honey for nutrition and health: a review," Journal of the American College of Nutrition, vol. 27, no. 6, pp. 677-689, 2008.

[26] Décret n²-10-385 du 23 joumada II 1432 (27 mai 2011).

[27] Q. A. Shah, F. Bibi, and A. H. Shah, "Anti-Microbial effects of olive oil and vinegar against Salmonella and Escherichia coli," Pacific Journal of Science and Technology, vol. 14, no. 2, pp. 479-486, 2013.

[28] M. O. El Hadj, A. H. Sebihi, and O. Siboukeur, "Qualité Hygiénique et Caractéristiques Physico-Chimiques du Vinaigre Traditionnel de Quelques Variétés de Dattes de la Cuvette de Ourgla," Rev Energ Ren Prod Valoris-Biomasse, vol. 6, pp. 87-92, 2001.

[29] A. Sbihi, "Contribution à l'étude de quelques paramètres de la qualité hygiénique et biochimique du vinaigre traditionnel de quelques variétés de dattes de la cuvette de Ouargla," Mém D’ingénieur INFSAS Ouargla, vol. 2, p. 2, 1996.

[30] W. Duan, T. Xia, B. Zhang et al., "Changes of physicochemical, bioactive compounds and antioxidant capacity during the brewing process of zhenjiang aromatic vinegar," Molecules, vol. 24, no. 21, p. 3935, 2019.

[31] S.-H. Kim, H.-K. Cho, and H.-S. Shin, "Physicochemical properties and antioxidant activities of commercial vinegar drinks in Korea," Food Science and Biotechnology, vol. 21, no. 6, pp. 1729-1734, 2012.

[32] M. H. Matloob, "Zahdi date vinegar: production and characterization," American Journal of Food Technology, vol. 9, no. 5, pp. 231-245, 2014.

[33] I. Ozturk, O. Caliskan, F. Tornuk et al., "Antioxidant, antimicrobial, mineral, volatile, physicochemical and microbiological characteristics of traditional home-made Turkish vinegars," LWT - Food Science and Technology, vol. 63, no. 1, pp. 144-151, 2015.

[34] Y. Theapparat, A. Chandumpai, and D. Faroongsarng, "Physicochemistry and utilization of wood vinegar from carbonization of tropical biomass waste. In: tropical forestsnew edition," IntechOpen, 2018.

[35] J. Chang and T. Fang, "Survival of Escherichia coli O157:H7 and Salmonella enterica serovars Typhimurium in iceberg lettuce and the antimicrobial effect of rice vinegar against E. coli O157:H7," Food Microbiology, vol. 24, no. 7-8, pp. 745-751, 2007.

[36] E. Medina, C. Romero, M. Brenes, and A. de CASTRO, "Antimicrobial activity of olive oil, vinegar, and various beverages against foodborne pathogens," Journal of Food Protection, vol. 70, no. 5, pp. 1194-1199, 2007.

[37] T. S. El-Sayed, M. M. Nour El-Deen, M. E. Rokaya, and M. M. Sherif, "Evaluation of the antibacterial effect of apple vinegar as a root canal irrigant using endovac irrigation system," Al-Azhar Dental Journal for Girls, vol. 6, no. 1, pp. 53-59, 2019.

[38] N. K. K. Hindi, Z. K. A. AL-Mahdi, and Z. A. G. Chabuck, "Antibacterial activity of the aquatic extractof fresh, dry powder ginger, apple vinegar extract of fresh ginger and crud oil of ginger (Zingiber officinale) against different types of bacteria in hilla city," Iraq. Prostate, vol. 3, p. 6, 2014.

[39] D. Yagnik and V. Serafin, "J. Shah A. Antimicrobial activity of apple cider vinegar against Escherichia coli, Staphylococcus aureus and Candida albicans; downregulating cytokine and microbial protein expression," Science Report, vol. 8, no. 1, 2018.

[40] W. A. Rutala, S. L. Barbee, N. C. Aguiar, M. D. Sobsey, and D. J. Weber, "Antimicrobial activity of home disinfectants and natural products against potential human pathogens," Infection Control \& Hospital Epidemiology, vol. 21, no. 1, pp. 33-38, 2000.

[41] B. Kj, F. Breidt, and R. F. McFeeters, "Protective effects of organic acids on survival of Escherichia coli O157: H7 in acidic environments," Applied and Environmental Microbiology, vol. 72, no. 1, pp. 660-664, 2006.

[42] I. N. Hirshfield, S. Terzulli, and C. O’Byrne, "Weak organic acids: a panoply of effects on bacteria," Science Progress, vol. 86, no. 4, pp. 245-270, 2003.

[43] M. R. Alberto, M. A. Rinsdahl Canavosio, and M. C. Manca de Nadra, "Antimicrobial effect of polyphenols from apple skins on human bacterial pathogens," Electronic Journal of Biotechnology, vol. 9, no. 3, p. 0, 2006.

[44] S. Jelodarian, A. H. Ebrahimabadi, and F. J. Kashi, "Evaluation of antimicrobial activity of Malus domestica fruit extract from Kashan area," Avicenna J Phytomedicine, vol. 141, no. 1, p. 1, 2013. 
[45] M. Forina, S. Lanteri, and C. Armanino, "Chemometrics in food chemistry," Chemometrics and Species Identification, pp. 91-143, 1987. 